\title{
Judge's Role in Court to Eradicate Corruption According to Law Number 20 in 2001 (Study of Decision 16/PID.SUS.K/2011/PN.MDN)
}

\author{
Rizkan Zulyadi \\ Universitas Medan Area (UMA), Medan, Indonesia \\ rizkan@staff.uma.ac.id
}

\begin{abstract}
The main issues in this paper are as follows judge's role in court to eradicate corruption according to law number 20 in 2001 (Study of Decision 16/PID.SUS.K/2011/PN.MDN). This type of research is normative or normative juridical or library legal research which can be interpreted as legal research by examining library materials and secondary materials.The nature of this study is descriptive analytical.This research will be carried out by the researcher is Medan Disrict Court, having his address at Court Road No. 8 Medan Medan City, North Sumatera Province This research will be carried out by researchers starting in December 2018 until completion Data collection techniques are used in writing this essay are through library research techniques and also through the help of electronic media, namely the internet, and the method of data analysis conducted by the author is to use a normative legal approach that examines secondary data. The result shows that the role of the judge in an effort to eradicate corruption cases in the Medan District Court contained in the Decision Study 16/PID.SUS.K/2011/PN.MDN, namely to prosecute the process of corruption cases and impose corruption penalties with imprisonment during 2 (two) years 6 (six) months and a fine of Rp. 50,000,000 (fifty million rupiahs), provided that the fine is not paid, it must be replaced with imprisonment for 2 (two) months.
\end{abstract}

Keywords

judge's role; crime; corruption; Law Number

20 Year 2001

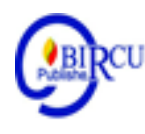

\section{Introduction}

In Indonesia, the law has existed for a long time, both before and after independence, the Old Order era, the New Order, and continued until the Reformation era. Various efforts have been made to eradicate corruption, but the results are still far from satisfying. In the past, there was a custom of taking "tribute" from the small people, which continued in the Dutch era when they controlled the archipelago since (1800-1942) and the British Age since (1811-1816). As a result of this policy, there were many popular resistance against the Dutch, for example the Diponegoro resistance since (1825-1830), Imam Bonjol since (1821-1837), Aceh since (1873 - 1904) and others.

The existence of a court is an institution in society that has been accepted by various social groups, not only as a legal institution that examines and adjudicates, but can also be seen as an economic and political institution as well as building community expectations for justice and others. The court itself cannot be seen merely as a legal institution because it is in no way fully described. National courts in developing countries such as Indonesia, are considered synonymous with the legal, cultural and political economic systems of the countries where the courts are located. The court as the implementing agency of the judicial authority actually has a very important function, the existence of a judicial institution is the main characteristic of a rule of law. 
At present the government is also aggressively aggressively eradicating corruption, we are faced with law enforcement in this corruption case which is quite paradoxical and is still far from a sense of community justice. One of them is the growing conviction of district court judges who handed down light sentences, even to the point that there were several acquittals free of defendants in corruption cases.

This is where the importance of openness and honesty of a judge in adjudicating corruption cases in his hands is expected to bring change for this country as well as for the development of law in Indonesia. Openness and honesty in addition to having an outward meaning but also contain an inner meaning, with the openness and honesty of a judge will create good law enforcement as expected by the people. Based on the description in the background, the authors are interested in conducting research and pouring it into a thesis entitled "Judge's Role in Court to Eradicate Corruption According to Law Number 20 in 2001 (Study of Decision 16/PID.SUS.K/2011/PN.MDN)".

\section{Review of Literature}

\subsection{Overview of Judges}

The supervisory and observer judge legal institution is a new institution in the field of criminal procedure law. Initially this institution started with Article 33 Paragraph (2) of Law Number 14 of 1970 concerning Basic Provisions of Judicial Power which gave a new task to the Head of District Court to supervise the implementation of court decisions. While the implementation of the court's decision was carried out by the Prosecutor.

According to Article 1 point 8 of the Criminal Procedure Code (KUHAP) which states that: "Judges are state court officials who are authorized by the Act to try".

a. Main Duties and Functions of Judges

According to Wisnu Broto (2015) the function of judges consists of 5 (five) types, as follows:

- Judicial Function

The first function of the judge, who is the supreme leader of the Judges in the Grand Makhamah is the judicial function. The function of this court is related to the functions and also the main task, both the supreme judge and ordinary judges in hearing a case.

- Oversight function

The next function held by the judge is the oversight function. The function of supervision or supervision is related to the function of the Supreme Court justices as supervisors who oversee every judicial process carried out in this country, both from low court levels or mild cases, to cases that are very severe and become a national, even international issue.

- Regulating Function

The function of regulating which is owned by the Supreme Court justices and also the Supreme Court refers to the function of this State institution as the giver of rules and also certain regulatory restrictions concerning judicial activities in all regions of Indonesia. The function of regulating this is done, especially if there are certain rules that are not listed in the Act, the code of ethics, or community norms, which can affect the proceedings of the court. 


\section{- Advice Function}

The function of this advice is the next function of the Supreme Court Justice and also the Supreme Court in providing advice, consideration, and other guidance as deemed necessary, thus helping to smooth the ongoing justice process.

- Administrative functions

The Chief Justice, who in this case presides over what we know as the Great Makhamah, has a function known as an administrative function. This administrative function is the function of the Chief Justice and also the Supreme Court as a State institution which oversees various other State institutions.

\section{b. Judge Authority}

Authority is a right granted by law which is justified according to existing regulations. All levels of justice which according to their territory can adjudicate cases submitted to them with due regard to absolute authority, namely the power of attribution and their relative power, namely the provision of court types, all of which are regulated in the Law.

In order to sentence the defendant, the judge must be based on a case delegation document containing the entirety of the defendant's indictment and guilt. Then the judge in making a guilty decision or not the suspect can not be separated from the results of the evidence during the examination and trial. This can be proven by what we usually see in court cases where sometimes it takes weeks to months or even up to 1 year, then 1 case is resolved because the judge in carrying out his duties and to take decisions must also be based on information witnesses, evidence, testimony of the defendant / expert and facts revealed at the time the trial took place as well. In line with the duties and authorities of judges as above, namely the ability of judges to make decisions that are acceptable to the public. Therefore, and based on the matters stated above, the judge can render a verdict in the best and fairest manner without any coercion or intervention from any party.

\subsection{General Review of Corruption Crimes}

Corruption is a specific criminal act which is regulated outside of the Criminal Code, Corruption is a criminal act which involves bribery manipulation and acts against the law that are detrimental or can harm the country's finances or the country's economy, detrimental to the welfare or interests of the people / general. Acts that are detrimental to the country's finances or economy are corruption in the material field, while corruption in the political field can be realized in the form of manipulating the vote by bribery, coercion intimidation and or interference that affects the freedom of choice to vote-commercialize in the legislative body or in administrative decisions in the field of implementation government.

According to Syed Hussein (2015) Alatas characteristics of corruption, as follows:

- Characteristics of corruption always involve more than one person. This is what distinguish between corruption and theft or embezzlement.

- Characteristics of corruption are generally confidential, closed, especially motives the background of the change of corruption.

- Characteristics of corruption that involves elements of the obligation and the benefits of lead behind. These obligations and benefits are not always in the form of money.

- Characteristics of corruption, which is trying to take cover behind legal justification. 
- Characteristics of corruption, those who are involved in corruption are those who own it power or authority and influence those decisions.

- Characteristics of corruption, namely every action containing fraud, usually on public bodies or on the general public.

- Characteristics of corruption, which is that each form involves a dual function contradictory of those who carry out these actions.

a. Forms of Corruption

The form of a criminal act of corruption is the formulation of a criminal act of corruption which stands alone and is contained in Act Number 20 of 2001 of the Corruption Crime. In this Law, it is clearly formulated regarding certain elements which are threatened with certain criminal threats and criminal sanctions.

- Corruption of corruption by enriching oneself, another person or a corporation

- Acts of corruption by abusing the authority of opportunity, facilities or position.

- Bribery Corruption

b. Reasons for Corruption

According to Djoko (2014) the causes of corruption, are as follows:

- Lack of salary or income of civil servants compared to daily needs are increasingly increasing.

- Management irregularities,

- Modernization

- Mental emotions, and

- A combination of factors.

Meanwhile, according to Syed Hussein Alatas corruption occurs due to factors, namely as follows

- Absence or weakness of leadership in key positions is able to provide inspiration and influence one's behavior taming corruption,

- Weaknesses in religious and ethical teachings,

- Colonialism,

- Lack of education,

- Poverty,

- Lack of harsh punishment,

- Scarcity of a fertile environment for anti-corruption behavior,

- Government structure,

- Radical change, and

- The state of society.

Hehamahua (2014) saw three factors causing corruption in Indonesia, namely: first, high consumption and low salaries. It is common knowledge that Indonesian society is a very consumptive society, not a few who go shopping abroad while the average salary of employees in Indonesia is only two weeks. The fate of the next two weeks depends on the creativity of each one of them by conducting KKN (Corruption Collusion and Nepotism). Second, supervision of ineffective development. Because of weak development supervision, it opens up the broadest opportunities for misuse such as mark ups and so forth, and thirdly, the greedy attitude of officials. 


\section{Research Method}

This type of research is normative or normative juridical or library law research which can be interpreted as legal research by examining library materials and secondary material enis. Secondary material. This research will be carried out by researchers starting in December 2018 until completion.

\section{Discussion}

\subsection{Corruption Crime Management Policy}

Corruption is one big problem that has always been a concern of the community. Not only a concern of the international community. In the Resolution on "Corruption in Government" accepted by the 8th UN Congress on "The Prevention of Crime Treatment of Offenders" in Havan (2015). Among other things stated, that:

a. Corruption among public officials "corrupt activities of public official", namely as follows:

- Can destroy the potential effectiveness of all types of programs government "can destroy the potential effectiveness of all types of governmental programs ".

- Can disrupt / hinder the development of "hinder development" and

b. Causing individual victims or community groups "victimize individuals and groups ".

There is a close relationship between corruption with various forms of economic crime, organized crime, and money laundering.

\subsection{Corruption in the Criminal Code}

The Criminal Law Act that was applied in Indonesia since January 1, 1918 is a Dutch heritage. It is a codification and unification that applies to all groups in Indonesia based on the principle of concordance, promulgated in Staatblad 1915 Number 752 based on KB 15 October 1915.

In the course of the Criminal Code has been amended, added, and improved by several national laws such as Law Number 1 of 1946, Law Number 20 of 1946, and Law Number 73 of 1958, including various Laws on combating corruption which regulates more specifically some of the provisions in the Criminal Code. Corruption in the Penal Code covers offenses for positions and those related to position offenses.

\subsection{Regulations on the Eradication of Corruption of the Central War Ruler Number PRT / PEPERPU / 013/1950}

Opinions stating that corruption is caused partly by the poor regulation that has been known for a long time. Thus the opinion that the improvement of anti-corruption regulations will bring about the reduction in corruption remains a debate.

Regulations that specifically regulate the eradication of corruption are Regulations on Eradication of Corruption in Central War Rulers Prt / Peperpu / 013/1950 Number, which were then followed by Military Rulers Regulation dated April 9, 1957 Prt / PM / 06/1957 number, May 27, 1957 Prt / PM / 03/1957 number, and date July 1, 1957 Prt / PM / 011/1957 Number. The important thing to know from the rules above is the first attempt to use the term corruption as a legal term and limit members to the notion of corruption as "acts that are detrimental to the country's finances and economy". 


\subsection{Law Number 24 (PRP) of 1960 concerning Corruption Crimes}

The Central War Ruler's Regulation on the Eradication of Corruption is emergency, temporary, and based on the Danger Law. Under normal circumstances he needs adjustment. Based on the consideration of adjusting the situation, the Act No. 24 (PRP) of 1960 concerning the Eradication of Corruption Crimes was originally formed in the form of a Government Regulation in Lieu of Law. The main change from the Central War Rulers Regulation to this Act was the conversion of the term deed into a criminal offense. However, this Law was found to be too light and advantageous for the accused considering the proof was more difficult.

\subsection{TAP MPR No. XI / MPR / 1998 concerning State Organizers that are Clean and Corruption-Free, Collusion and Nepotism}

As the reform movement arose from the people's dissatisfaction with the New Order's rule for nearly 32 years, the desire to develop a new life order towards civil society developed in Indonesia. The desire to formulate a new order that prioritizes civil society begins with the preparation of a set of laws and regulations which are considered to prioritize the interests of the people as demands have removed Suharto from the presidency.

Through the implementation of the MPR Special General Session, TAP No. XI / MPR / 1998 concerning Clean and Corruption-Free, Collusion and Nepotism State Administrators. This MPR TAP contains many mandates to form legislation that will oversee the development of the reform order, including the mandate to resolve legal issues against former President Soeharto and his cronies.

\subsection{Law Number 20 of 2001 concerning Amendment to Law Number 31 of 1999 concerning Eradication of Corruption}

Law Number 20 of 2001 is a Law that was born solely to correct the weaknesses and shortcomings of the previous Law. As mentioned above, some of these weaknesses were later revised in the new Law. The revisions to the weaknesses of Law Number 31 of 1999 are as follows:

- Withdrawal of certain articles from the Criminal Code as a criminal act of corruption is done by adopting the contents of the article as a whole so that changes in the Criminal Code will not result in asynchronization.

- The regulation of reasons for capital punishment is based on corrupt acts carried out on funds used to deal with certain conditions such as a state of danger, national disaster, and monetary crisis.

- Inclusion of a transitional regulation that expressly acts as a bridge between the old Law that has expired and the existence of a new Law, so that it no longer creates the risk of a legal vacuum that can adversely eradicate corruption.

\subsection{Judge's Role in Court to Eradicate Corruption According to Law Number 20 in 2001}

Eradicating corruption has become one of the topics of discussion for a long time, so when the Attorney General announced his determination and the issuance of a presidential 
decree that could not be separated from the spirit to realize and create a clean and authoritative government as one of the manifestations of the implementation of the 1945 Constitution purely and consequent. This is also reflected in creating a clean and authoritative government. In eradicating corruption cases handled by the court which are charged by the judge to solve them, so far it has been carried out accordingly even though there are still many obstacles here and there encountered by the judges in their eradication efforts.

One of the roles of the judge in an effort to eradicate corruption cases is found in the Medan Court of Decision Study 16 / Pid.Sus.K / 2011 / Pn.Mdn, who tried the process of corruption cases with the defendant Ir. H. Kurnia R. Saragih.47 The judge sentenced Ir. H. Kurnia R. Saragih on the basis of consideration of the element of who, this element is solely to show that the offense is general, the defendant as regulated and threatened with crime in article 3 of Law Number 31 of 1999, which has been amended by the Law Number: 20 of 2001 concerning Amendments to the Republic of Indonesia Law Number: 31 of 1999 concerning Eradication of Corruption Crimes jo. Article 55 paragraph (1) of the Criminal Code. Article 18 of Law Number 31 of 1999 which has been amended by Law Number: 20 of 2001 concerning Amendment to the Law of the Republic of Indonesia Number: 31 of 1999 concerning Eradication of Corruption.

Judge's consideration is also based on the element of breaking the law here is an act that is formally and materially contrary to the provisions or contrary to the law. Laws, regulations based on witnesses' testimony Sudirmanpurba Siboro, BBA, Waldemar Napitupulu, S.H, Agus Salam, SE, Robert Dontes Simatupang, SE, Harun Harahap, Drs. Paian Siagian, Ir. Albert Nainggolan, Dr. Andi Rangkuti, Pananakan Sihombing, Lomo Gultom, Salim Tarigan, and Tisah Rianto Sinamo that Ir. H. Kurnia R. Saragih as Acting Mayor of Pematang Siantar has responsibility for the financial administration aspect of the annual APBD implementation and is given the authority to refuse the submission of employment service memorandum, but based on the facts in court the Defendant approves the payment of long service official submission submitted by the Health Service, The General Section and Equipment, the PUK Service and the Sanitation and Environment Service, even though the Defendant was consciously aware that the 2005 Fiscal Year's Regional Budget was not yet ratified, and as a result the defendant's actions could cause state losses in this case. Pematang Siantar City Government experienced a lack of Regional Cash in the 2005 Fiscal Year. In addition there is also an element of enriching oneself or another person or entity Article 1 Paragraph 1 sub b of Law Number 3 of 1971.

Based on the facts in the trial, Defendant Pramono as the defendant is clearly committing a criminal act of corruption against the law which has used the means available to him for his own interests and has enriched himself in a way against his rights. Based on these matters, namely Article 1 paragraph 1a of Law Number 3 of 1971, enriching oneself is proven legally according to the Law.

In addition, the panel of judges also argued that there were things that were burdensome for Ir. H. Kurnia R. Saragih, namely the Defendant did not support the government's program in combating corruption. Considering, based on these matters, the judge tried and handed down the verdict that sentenced Ir. H. Kurnia R. Saragih has been proven to have committed acts corruption with imprisonment for 2 (two) years 6 (six) months and a fine of Rp. $50,000,000$ (fifty million rupiahs), provided that the fine is not paid, it must be replaced with imprisonment for 2 (two) months. Based on the decision above, it can be seen that the judge tries to carry out his duties well and is consistent with the Law. The judge tried to provide 
maximum performance in eradicating corruption by adjudicating cases submitted to him, as well as giving verdicts that were appropriate and wanted by law. The obstacle faced by judges in the Medan district court is the difficulty or difficulty of bringing corruption cases to court. This is far more difficult than carrying a conventional case.

It is difficult to bring a corruption case to the surface or to court because it is feared that it will expose the depravity of the officials who control this country with power other than not the least law enforcement officers involved in the corruption case.

The problem of law enforcers such as the police, prosecutors and judges who handle corruption cases is indeed a lot of corruption. They indeed tend to be corrupt and many proven in the field to strengthen these assumptions. One of the drivers or factors is the large number of officials or law enforcement officials due to corruption involving the business of billions or trillions of rupiah and dollars. The problem faced by a judge besides the difficulty of presenting a case of surface corruption, is another obstacle faced by the judge in a district court it is difficult to bring the defendant forward / to trial before trial for trial, which in law is often called in absentia. Lack of legal officers or law enforcement agencies dealing with corruption.

Another obstacle faced by judges in court is when they are tried, especially when giving sentences or decisions that often make the judges confused, there is no prudential jurisprudence regarding the payment of corruption substitute money which is an additional crime, but it is not regulated about substitute confinement if no compensation is paid. it was corrupted, there was only the Supreme Court fatwa, so questions arose that would naturally arise from the public how to collect the replacement money and whether it was enough for the Supreme Court fatwa to provide legal certainty.

\section{Conclusion}

The legal regulation of criminal acts of corruption in Indonesia, namely the enactment of Law Number 31 of 1999 concerning corruption and criminal sanctions, is mentioned starting from Article 2 to Article 20. Then in Chapter IV from Article 25 to Article 40 it contains the formal provisions on how to carry out the material provisions. The government then made changes to Law Number 31 of 1999 by issuing Law Number 20 of 2001 concerning Eradication of Corruption. The formula was amended by not referring to the articles in the Criminal Code but directly mentioning the elements contained in each of the articles of the Criminal Law referred to. In terms of sanctions, Law Number 20 Year 2001 stipulates much lighter sanctions than those stipulated Law Number 31 Year 1999. For effective eradication of corruption, the government established the Corruption Eradication Commission with the issuance of Law Number 30 of 2002 Concerning the Eradication Commission Corruption Crime. Finally, the government issued Law Number 15 of 2002 concerning Money Laundering.

The basis of the judge's judgment in issuing a ruling on corruption is divided into two categories, namely juridical considerations and non-juridical considerations. Juridical considerations in the form of indictments by the public prosecutor, the defendant's statements, witness statements, evidence and articles in the regulations criminal law of corruption. Whereas the non-judicial consideration is in the form of the defendant's background, due to the actions of the accused, the defendant's self condition and the defendant's religion. 
The role of the judge in an effort to eradicate corruption in the Medan District Court contained in the Decision Study 16 / Pid.Sus.K / 2011 / PN.MDN, which is to adjudicate the process of corruption cases and impose corruption penalties with imprisonment for 2 (two) year 6 (six) months and a fine of Rp. 50,000,000 (fifty million rupiahs), provided that if the fine is not paid it must be replaced with imprisonment for 2 (two) months.

\section{References}

Alatas, Syed Hussein. Sosiologi Korupsi: Sebuah Penjelajahan Dengan Data Kontemporer, LP3ES, Jakarta, 2015.

Asshiddiqie, Jimly. Sengketa Kewenangan Konstitusional Lembaga Negara, Konstitusi Press, Jakarta, 2016.

Barda Nawawi, Arief. Beberapa Aspek Kebijakan Penegakan dan Pengembangan Hukum Pidana, Penerbit PT. Citra Aditya Bakti, Bandung, 2015.

Friedrich, Carl J. Constitutional Government and Democracy Theory and Practise in Europe and America, Blaidell Publishing Company, Weldha, 2014.

Hamid, Praktek Peradilan Perkara Pidana, CV. Al-Ikhsan, Surabaya, 2015.

Hehamahua, Abdullah. Membangun Gerakan Antikorupsi Dalam Perspektif Pengadilan, LP3 UMY, Yogyakarta, 2014.

Julian, D.M Lew. Applicate Law in International Commercial Arbitration, Netherlands Sijthoff an Norhoff, 2014.

Mulyadi, Lilik. Putusan Hakim dalam Hukum Acara Pidana: Teori, Praktik, Tehnik Penyusunan dan Permasalahannya. Citra Adtya Bakti, Bandung 2016.

Oomar Sono, Adji. Hukum-hakim Pidana, Penerbit Erlangga, Jakarta, 2016.

Pompe, Perbuatan Pidana dan Pertanggungjawaban Pidana, Bintang Indonesia, Bandung, 2015.

Prakoso Djoko, Alat Bukti dan Kekuatan Pembuktian Di Dalam Proses Pidana, Liberty, Yogyakarta, 2016.

Santoso, Topo. Penulisan Karya Ilmiah Urgensi Pembenahan Pengadilan Tindak Pidana

Sudarto, Hukum dan Hukum Pidana, Alumni, Bandung, 2016. 